\title{
Prevalence and Distribution of Cassava Bacterial Blight in the Kenyan Coast
}

\author{
A. Livoi ${ }^{1 *}$, A. W. Mwang'ombe ${ }^{1}$, E.Nyaboga $^{2}$, D. Kilalo ${ }^{1}$ \& E. Obutho ${ }^{1}$ \\ ${ }^{1}$ Department of plant science and crop protection, University of Nairobi, Nairobi, Kenya \\ ${ }^{2}$ Department of Biochemistry, University of Nairobi, Nairobi, Kenya \\ Correspondence: Antony Livoi Musera, Department of plant science and crop protection, University of Nairobi, \\ Po Box 30197-00100, Nairobi, Kenya. E-mail: livoiantony@gmail.com
}

Received: November 11, 2020 Accepted: November 26, $2020 \quad$ Online Published: February 18, 2021

The research is financed by (Regional universities forum for capacity building in Agriculture: RUFORUM)

\begin{abstract}
Cassava (Manihot esculenta Crantz) is one of the staple food crops grown in Kenya. Diseases remain one of the major constraints for cassava production. Apart from other major viral diseaes Cassava mosaic and Cassava brown streak, Cassava bacterial blight (CBB) caused by Xanthomonas axonopodis pv manihotis and Xanthomonas axonopodis pv cassavae are a major constraint in cassava production in Kenya. This study was done to identify the prevalence, distribution, and farmers' knowledge of cassava bacterial blight in the coastal region of Kenya. A survey was conducted involving 250 farmers who were randomly selected from two regions of Kilifi and Taita Taveta counties. Among the 250 farmers interviewed, $61.6 \%$ identified cassava bacterial blight symptoms in their farms. The main varieties found growing in the region were Tajirika, Karembo, Kibandameno, and Shibe which were all confirmed by farmers as susceptible to cassava bacterial blight. During the survey, plant samples were randomly collected in the field. Out of the 70 samples collected, 40 of them were confirmed positive with $X$.pv manihotis and X.pv cassavae which cause cassava bacterial blight. The study concluded that there is a widespread of cassava bacterial blight in Kilifi and Taita taveta counties. Kilifi County had the highest incidence of $22 \%$ with Taita Taveta having the lowest incidence of $13 \%$. Kilifi County had a higher severity of $8 \%$ as compared to Taita Taveta which had 5\% Severity. Therefore there is a need for a proper management program to be deployed in managing the disease to enhance cassava production in the region.
\end{abstract}

Keywords: Cassava, Survey, Incidence, $X$. axonopodis pv manihotis, $X$. axonopodis pv cassavae

\section{Introduction}

Cassava manihotis esculenta is one of the major crops grown and consumed in the sub-Saharan Africa. It provides carbohydrates for more than 800 million people in Africa (FAO, 2017). Cassava production quantity in Kenya is at 946,076 metrics tones from 61,592 of hectares of land (FAOSTAT 2018). Western Kenya is the leading producer of cassava, followed by the coastal regions (MOA 2007; Abong' et al., 2016). The crop is grown for its tubers which provide starch and carbohydrates and leaves which are rich in protein and other minerals like calcium, iron and phosphorous. Production of cassava is on the increase as compared to the years back and this is because it has potential in adapting to climate change, food security and also an industrial potential to produce starch and feed for animals.

Cassava is faced by challenges both biotic and abiotic challenges. One of the main biotic challenges is Cassava bacterial blight, caused by Xanthomonas axonopodis pv. manihotis and Xanthomonas axonopodis pv. cassavae (Verdier et al .,1994); (Ogunjobi \& Fagade, 2008). The disease is commonly spread through infected planting materials (Lozano et al., 1980). Since the pathogen exists in stems in latent form, it is not easy to detect the disease. Therefore, farmers have played a major role in disseminating the disease unknowingly by sharing planting materials over long distances (Taylor, 2009). In Kenya, the disease was first reported in western region (Mukunya et al., 1980). Survey done in 2016 across the country in cassava growing regions indicated that cassava bacterial blight exists in all the cassava growing regions (Odongo et al., 2016). This study was conducted to determine the prevalence of cassava bacterial blight in two cassava growing regions of Kilifi and Taita Taveta counties in coastal Kenya. 


\section{Materials and Methods}

\subsection{Survey of Cassava Bacterial Blight and Sample Collection}

A survey was conducted in two counties along the Kenyan coast. This was Kilifi county and Taita taveta county as geographically described below.

\section{Taita Taveta County}

It is one of the counties in the coastal region known for its tourist attraction sites and wildlife. The county has some neighboring counties including Makueni, Tana River, and kitui in its North direction. It borders Kilifi and Kwale in its East direction. On the south, the county borders the Republic of Tanzania. As per the census done in 2019 the county is home to a population of 340,671 people with an area of 17,084 km2. (Kenya county fact sheet, 2011).

Topographically, the County has three major zones. The upper zone comprises Taita, Mwambirwa, and Sagalla hills regions with altitudes ranging between 304 and 2,208 meters above sea level. The lower zone has plains while the third zone is the volcanic foothills zone covering the Taveta region. The region has two lakes, Jipe and Challa, both found in Taveta. The County is largely dry although Taita hills are wetter. Two rainy seasons are experienced, long rains between March and May while the Short rains occur between October and December. The annual mean rainfall is estimated at $650 \mathrm{~mm}$. Some of the crops grown in this region include: cassava, sweet potato, vegetables, sorghum, millet, green grams, cow pea and macadamia.

\section{Kilifi County}

It is one of the counties touching the Indian Ocean and known for its best beaches that attract both local and international tourists. It hosts a population of around 1,109,735 people as per the census done in the year 2009. It has a geographical size of 12,245 km2 according to Kenya's independent electoral and boundaries commission. It is quite large and has seven counties including Magarini, Malindi, Ganze, Rabai, Kaloleni, Kilifi South, and Kilifi North.

Crops grown in this region include coconut, cassava, cashew nuts, maize, sweet potatoes, and legumes. The county has a warm climate with temperatures ranging from $21^{\circ} \mathrm{C}$ during the cold month and up to $32^{\circ} \mathrm{c}$ during the hottest months. It receives an annual rainfall of $900 \mathrm{~mm}$ to $1000 \mathrm{~mm}$, with long rains experienced in April to June and short rain experienced in October to December. (Kenya county fact sheet, 2011).

\section{Survey Conducting}

A survey was conducted in Kilifi and Taita Taveta counties in July 2018 during short rain seasons by randomly administering structured questionnaires to cassava farmers. Purposive random sampling was done whereby farmers were selected randomly at an interval of $2 \mathrm{~km}$ from each farmer for questionnaire administering. A sample size of 250 farmers were randomly selected from cassava farmers and interviewed during the survey for the two regions. All the questionnaires were brought back to the college, cleaned, and entered. The analysis was done using the science statistical package (SPSS).

Plant samples were collected in cassava fields both symptomatic for cassava bacterial blight and asymptomatic samples. Sampling was done on plants along diagonals and the number of samples collected per field depended on the variability of symptoms and field size (Trujillo et al., 2014 ). From the two sites of study 70 leaf plant samples were collected, 34 plant samples from Taita Taveta, and 36 plant samples from Kilifi County. This was done randomly on farms having cassava. They were then stored in brown envelopes and put in a cool box and transported to the College of Agriculture and Veterinary Science in the Department of plant science and crop protection and stored at $-4{ }^{\circ} \mathrm{C}$.

\subsection{Disease Assessment}

Disease assessment was done using the severity index and incidence index. Incidence was obtained by counting symptomatic plants in relation to total number of plants in the field according to the equation of Bansal.

$$
\text { Disease incidence }(\mathrm{DI} \%)=\frac{\text { Number of diseasedplants }}{\text { Totalnumber of plants }} \chi 100
$$

Disease severity was scored using a scale developed by (Wydra \& Misikita 1998) where: 1 - No symptom, 2 Angular leaf spots, 3 - Angular leaf spots, blight, wilt, defoliation, and sometimes exudates on stems, petioles or leaves, 4 -Blight on leaves, leaf wilt, defoliation, exudates, and tip dieback, and 5 - Blight on leaves, leaf wilt, defoliation, exudates, abortive lateral shoot formation, and stunting, complete dieback. Severity was obtained using the formula by song, et al. 


$$
S I \%=\frac{(\Sigma \text { Scale } \times \text { No of plants infected }}{\text { Highest scale } \times \text { Total number of plants }} \times 100
$$

To establish farmers' knowledge and perceptions on CBB in Coastal Kenya, information such as the source of planting material, age of the crop, name(s) of the cultivar(s) grown in the fields, disease management approaches used, source of information and the duration for which they have grown the crop were asked during questionnaire interview.

\subsection{Isolation of Bacteria from Collected Leaf Samples}

Isolation was done according to (Ogunjobi \& Fagade, 2008). Infected plant samples stored at $-4{ }^{0} \mathrm{c}$ were cut into small pieces of $2 \mathrm{~mm}^{2}$ and washed in sterile distilled water. The pieces were then washed in $3 \%$ sodium hypochlorite for 3 minutes and triple rinsed in sterile distilled water using the universal bottles. Yeast peptone glucose (YPG) broth was prepared containing yeast $1 \%$, peptone $1 \%$, and glucose $1 \%$. The cut infected parts were placed in universal bottles containing $10 \mathrm{ml}$ broth and placed on the rotary shaker at a speed of 100rpm for 48 hours at room temperature to allow the bacteria to ooze into the broth. The broth was then serial diluted to $10^{-6}$ and then from each dilution, a drop of $100 \mu \mathrm{l}$ was spread on plates containing freshly prepared selective media containing Yeast $1 \%$ peptone $1 \%$, glucose $1 \%$ and agar $1.5 \%$ (YPGA). The plates were then placed in an incubator for $28^{\circ} \mathrm{c}$ for 48 hours.

The bacterial colonies obtained were identified and used for pathogenicity tests on clean symptomless plants multiplied through tissue culture technique from tissues culture laboratory in the department of plant science and crop protection. After four weeks the symptoms were recorded and photos captured both for the infected plants and the control which were not infected. Re-isolation was done using YPGA to fulfill Koch's postulates.

\subsection{Data Analysis}

Data collected during the survey was cleaned, entered and analyzed using the statistical package for social science SPSS. Graphs showing the output of farmer response were developed using an Excel spreadsheet (2016)

\section{Results}

\subsection{Incidence and Severity of Cassava Bacteria Blight}

From the survey conducted in the study regions, Kilifi County had the highest incidence of $22 \%$ with Taita Taveta having the lowest incidence of $13 \%$. Kilifi County had a higher severity of $8 \%$ as compared to Taita Taveta which had 5\% Severity as seen in Figure 1. During the survey, a range of symptoms were observed as captured in Figure2 with the highest score of symptom remaining at 3 on the disease scale used. Angular leafspot, blighting, watersoaked lesions were visible but defoliation, bacterial exudates, abortive lateral shoot formation, stunting, and die back were not record as per the scale used. The grouping was done for the farms in which plant sampling was done as seen in Table 1 . There were farms which had $0 \%$ incidence and other farms were found in the highest scale grouping of $76-100 \%$

Table 1 . Showing incidence and severity scale grouping.

\begin{tabular}{lccccc}
\hline & scale 0\% & scale 1-25\% & scale26- 50\% & scale 51-75\% & Scale 76-100\% \\
\hline $\begin{array}{l}\text { TAITA-TAVETA } \\
\text { REGION }\end{array}$ & & & & & \\
$\begin{array}{l}\text { incidence } \\
\text { severity }\end{array}$ & 14 & 10 & 1 & 4 & 4 \\
KILIFI REGION & 16 & 8 & 10 & 1 & 0 \\
incidence & & & & & \\
severity & 20 & 9 & 2 & 3 & 2 \\
\hline
\end{tabular}

The table above shows how many sampled farms were found in each scale grouping for the two study regions of Taita Taveta and Kilifi at the Kenyan coast. 


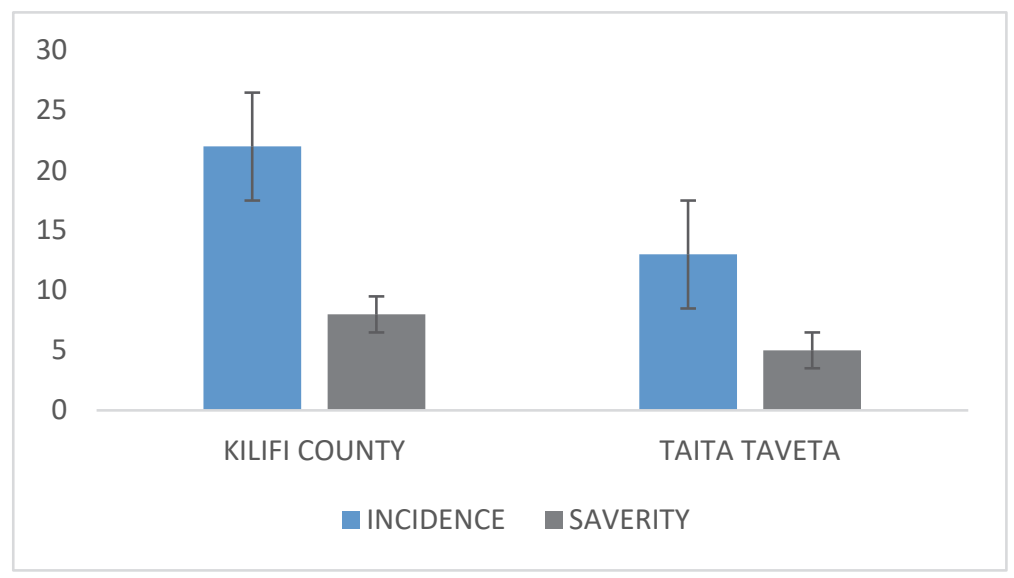

Figure 1. Incidence and severity of CBB on average in the two surveyed counties
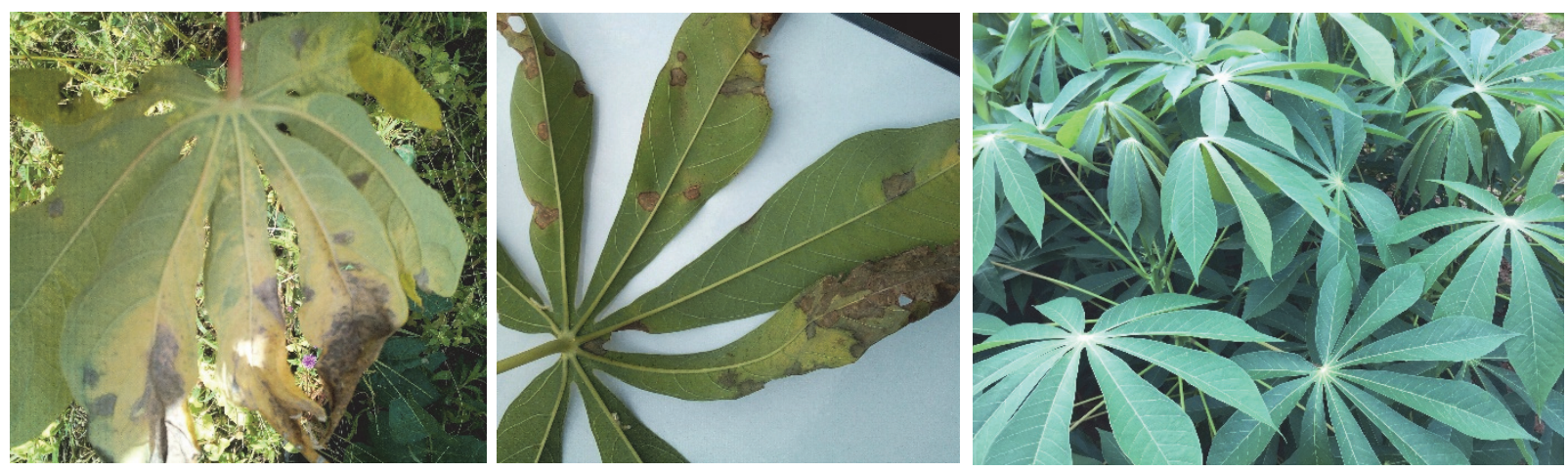

Figure 2. Showing symptoms on infected plants and clean non infected plants respectively

\subsection{Confirmation and Pathogenicity of the Isolates}

The isolated bacteria colonies ranged between whitish, creamish, and yellow with convex shape, shiny and mucoid as described by Wydra et al., 1990. Inoculation of the bacterial on the plants after 2 weeks showed blighting around the point of inoculation with the control showing no blighting at the point of inoculation as seen in Fig 3 hence indicating the pathogenicity of the bacteria.
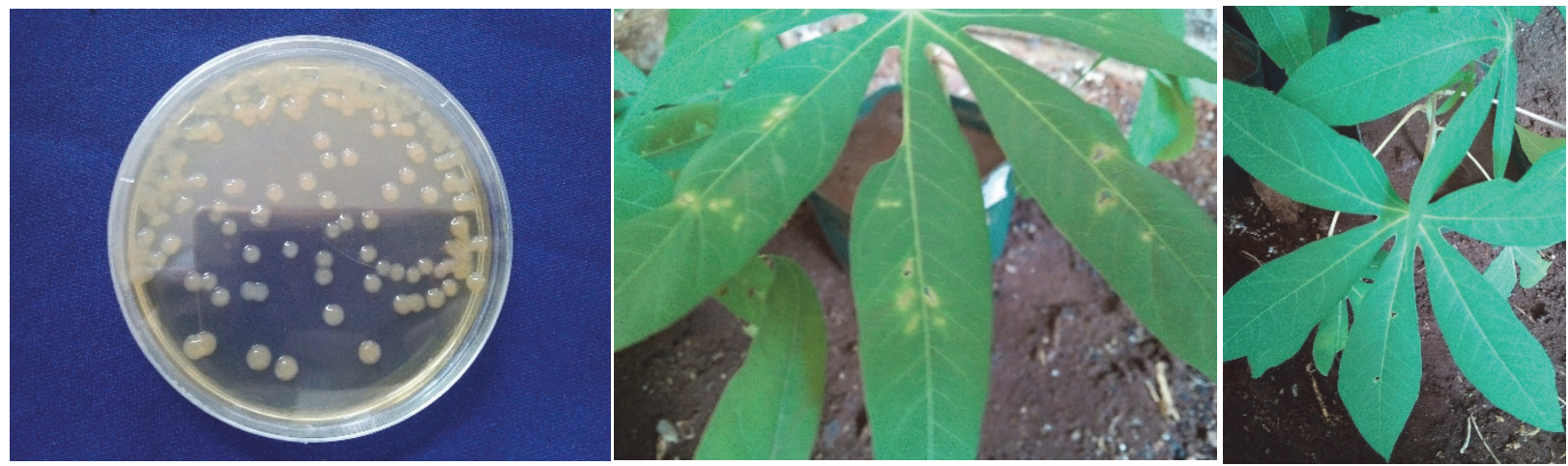

Figure 3. Showing Xanthomonas axonopodis pv. manihotis colonies isolated from plants collected in the field, infected plant showing symptoms and control plant showing no symptoms at the point of infection

\subsection{Distribution of CBB in Coastal Kenya}

Among the 70 plant samples collected from different farms in the field, Isolation was done and 40 samples showed bacteria characteristic to Xanthomonas axonopodis pv cassavae and Xanthomonas axonopodis pv manihotis. Of the 40 samples, 21 samples were from Taita Taveta and 19 samples were from Kilifi. The colonies obtained were mucoid, cream to whitish, circular, shiny and convex as described by Wydra et al., 1990. A distribution map was 
developed using ARCH GIS software and the incidence was grouped into four classes of 1-25\%, 26-50\%, $51-75 \%$ and $75-100 \%$ (Odongo et al., 2019). The geographical coordinates used to develop the map were taken using GPS tools at the point of sample collection in the field.

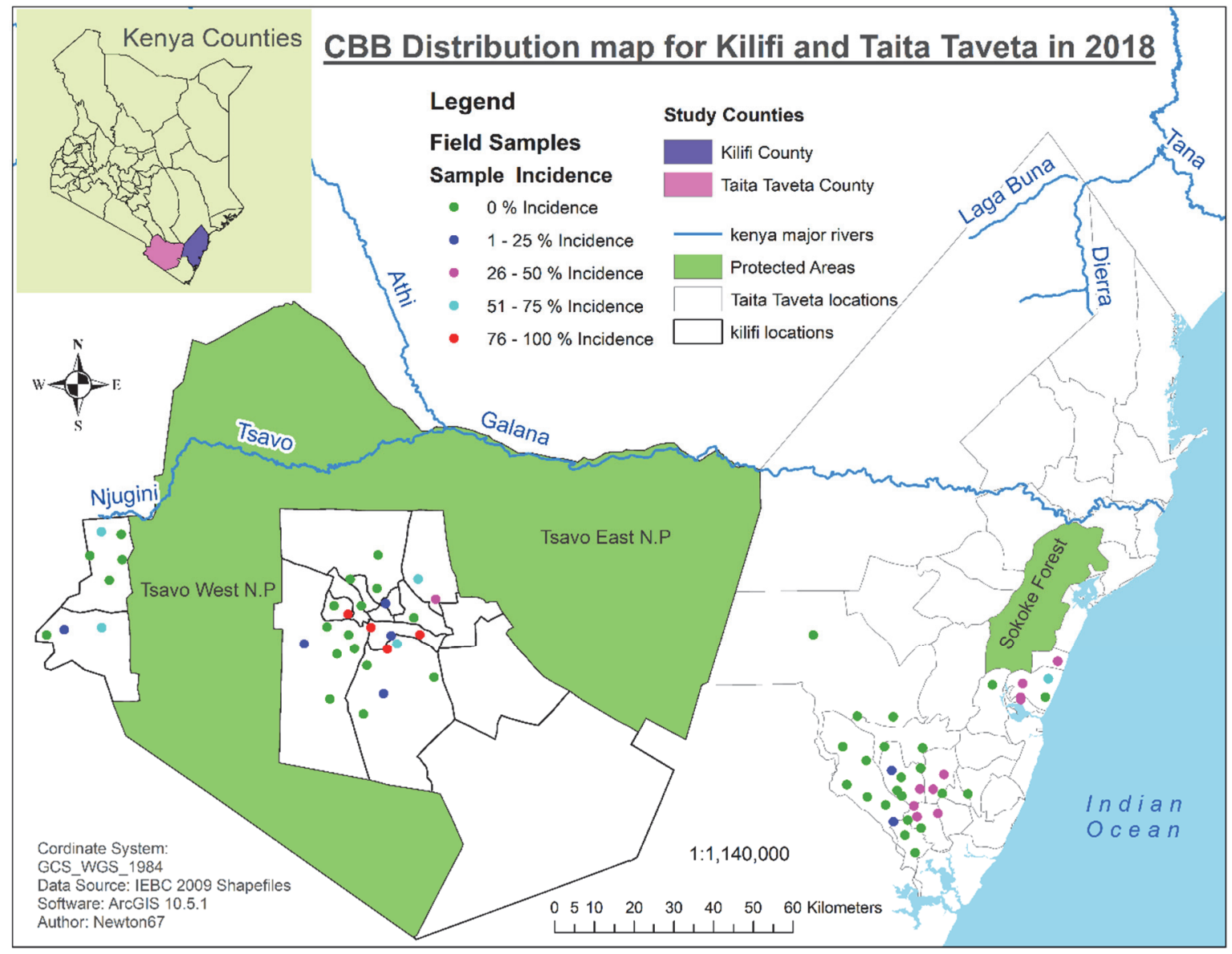

Figure 4. Distribution Map for CBB in Kilifi and Taita Taveta showing incidence levels in different places

\subsection{Farmers' Knowledge and Awareness of CBB}

During the survey a representative population of 250 farmers were interviewed, among them, $50.8 \%$ of the farmers were interviewed from Kilifi while $49.2 \%$ of the farmers were interviewed from Taita Taveta. Among the interviewed farmers, $61.6 \%$ of them had once interacted with symptoms characteristic to cassava bacterial blight as seen in the photos used during the survey. Farmers experiencing CBB every season in their farms were $43,6 \%$. Only $17.2 \%$ of the farmers reported having never seen CBB symptoms in their farms. Other farmers, $39.2 \%$ were not in a position to tell if they have once seen CBB in theirs farms since some were new in farming, others had only planted one season.

On resistance and susceptibility of the available varieties, $38 \%$ of the farmers reported Kibandameno variety as highly affected by the disease followed by Tajirika reported by $13.2 \%$ of the farmers. All the mentioned variety Shibe, Girikacha, and Kaleso were confirmed as susceptible to CBB by the interviewed farmers. There is no single farmer who reported a resistant variety in both the regions. Most farmers that is $80 \%$ of the interviewed, don't manage cassava bacterial, although they do intercropping with a major reason to maximize on their limited land space. 

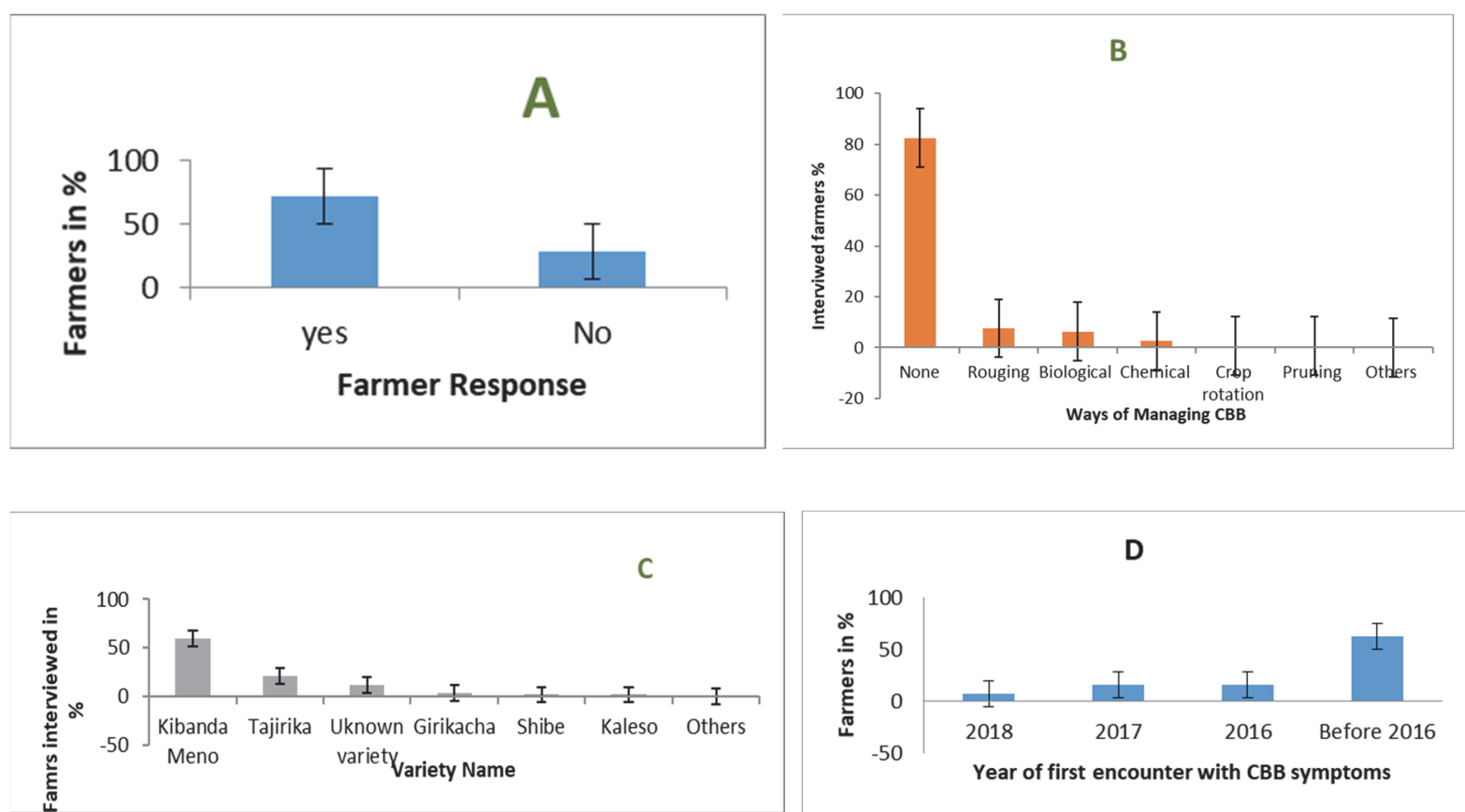

Figure 5. Graph A showing the seasonality existence of CBB. Graph B showing how farmers manage CBB. Graph C showing Varieties susceptible to CBB. Graph D showing the year in which farmers first interacted with CBB.

\section{Discussion}

The study shows that cassava bacterial blight caused by Xanthomonas axonopodis pv manihotis and Xanthomonas axonopodis pv cassavae is widely distributed in the coastal region of Kenya both in Taita Taveta and Kilifi counties visited during the study. This confirms work done by (Odongo et al., 2016; Chege et al., 2017) on the distribution of Cassava bacterial blight disease in Kenya. Their work similarly reported the presence of cassava bacterial blight in major cassava growing regions of Kenya. All the varieties grown both in Kilifi and Taita Taveta County are susceptible to cassava bacterial blight as referred to the response from the farmers who grow the varieties. An indication that there is no resistant variety for cassava bacterial blight in the region and no landrace variety has been identified by farmers in the region to show resistance to $\mathrm{CBB}$, this confirms work done on evaluation of resistance of cassava cultivars in Kenya on CBB. (Mbaringong et al .,2017).

Most of the interviewed farmers reported having seen the disease even before 2016 which was more than 3 years back from the year of study. This confirms that CBB has been in existence in the region for quite some time and it is not a new disease in the region hence proving work done on distribution of CBB in Kenya(Odongo et al., 2016)

Most of the farmers reported to have experienced CBB in their farms every season they plant cassava. This indicates that they could be starting their crop with infected planting materials or they don't do proper farm hygiene to remove crop debris from the previous crops to reduce the inoculum. This demonstrates the gap that exists among farmers in awareness and management of $\mathrm{CBB}$ as indicated in the study where by $80 \%$ of them who don't manage CBB.

\section{Conclusion}

The study proved the existence and distribution of cassava bacterial blight in all the study areas of Kilifi and Taita Taveta. Varieties grown in this region: Kibandameno, Tajirika, Girikacha, Shibe and kaleso which are both local varieties and improved varieties have shown to be susceptible to cassava bacterial blight. Therefore there is need to address the issue through developing plant resistant varieties. Farmers in this region are poor at managing the disease therefore need for developing an integrated management practice program and good communication system to disseminate information to farmers through extension officers. There is also an urgent need for a program on clean planting material so that as cassava farming uptake is increasing, farmers can access and use healthy planting materials for establishing the new crop. Unless such mitigation measures are put in place, the spread of the disease is likely to increase as cassava is being advocated for as a food security crop and climate smart crop. 
Due to inadequate planting materials and poor seed system in cassava farming, farmers keep exchanging and sharing the materials which are infected hence contributed to the risk of spreading the disease in the region.

\section{Acknowledgments}

The authors would like to appreciate the Regional universities forum for capacity building in Agriculture (RUFORUM) for supporting this work under the CARP project.

\section{References}

Abong', G. O., Shibairo, S., Wanjekeche, E., Ogendo, J., Wambua, T., Lamuka, P., ... Masha, C. K. (2016). Postharvest practices, constraints and opportunities along cassava value chain in Kenya. Current Research in Nutrition and Food Science, 4(2), 114-126. https://doi.org/10.12944/CRNFSJ.4.2.05

Affery, A. M., Abo, K., Tuo, S., N'Zué, B., \& Koné, D. (2017). Geographical distribution and incidence of cassava bacterial blight (Manihot esculenta Crantz) caused by Xanthomonas axonopodis pv. manihotis in two agroecological zones of Côte d'Ivoire. Plant Patholology Journal, 16, 1-11.

Álvarez, E., Llano Rodríguez, G. A., \& Mejía, J. F. (2012). Cassava diseases. Centro Internacional de Agricultura Tropical (CIAT).

Bamkefa, B. A., Bah, E. S., \& Dixon, A. G. (2011). Survey of the current distribution and status of bacterial blight and fungal diseases of cassava in Guinea. African Journal of Root and Tuber Crops, 9(1), 1-5.

Banito, A., Verdier, V., Kpémoua, K. E., \& Wydra, K. (2007). Assessment of major cassava diseases in Togo in relation to agronomic and environmental characteristics in a systems approach, 2(September), 418-428.

Bansal, V. K., Kharbanda, P. D., Stringam, G. R., Thiagarajah, M. R., \& Tewari, J. P. (1994). A comparison of greenhouse and field screening methods for blackleg resistance in doubled haploid lines of Brassica napus. Plant Disease, 78(3).

Chege, M. N., Wamunyokoli, F., Kamau, J., \& Nyaboga, E. N. (2017). Phenotypic and genotypic diversity of Xanthomonas axonopodis pv. manihotis causing bacterial blight disease of cassava in Kenya. Journal of Applied Biology \& Biotechnology, 5(02), 038-044.

Fanou, A. A., Zinsou, V. A., \& Wydra, K. (2018). Cassava Bacterial Blight: A Devastating Disease of Cassava. Cassava. https://doi.org/10.5772/intechopen.71527

Joseph, J., \& Elango, F. (1991). The status of cassava bacterial blight caused by Xanthomonas campestris pv. manihotis in Trinidad. Journal of Phytopathology, 133(4), 320-326.

Lozano, J. C., \& Terryl, E. R. (1976). Cassava Diseases and Their Control Foliar and Green Stem Pathogens, 156160.

Mbaringong, G. A., Nyaboga, E. N., Wang, V., \& Kanduma, E. (2017). Evaluation of Selected Cassava (Manihot esculenta Crantz) Cultivars Grown in Kenya for Resistance to Bacterial Blight Disease. World Journal of Agricultural Research, 5(2), 94-101.

Night, G., Asiimwe, P., Gashaka, G., Nkezabahizi, D., Legg, J. P., Okao-Okuja, G., .. Mutumwinka, M. (2011). Occurrence and distribution of cassava pests and diseases in Rwanda. Agriculture, Ecosystems and Environment, 140(3-4), 492-497.

Odongo, H. M., Miano, D. W., Muiru, W. M., Mwang, A. W., \& Kimenju, J. W. (2019). Distribution of Cassava Bacterial Blight and Reaction of Selected Cassava Genotypes to the Disease in Kenya, Journal of Natural Sciences Research, 9(4), 2019.

Ogunjobi, A. A., \& Fagade, O. E. (2008). Physiological Studies on Xanthomonas axonopodis Pv Manihotis ( Xam ) Strains Isolated in Nigeria. Advances in Biological Research, 2(5-6), 90-96.

Onyeka, T. J. (2004). Distribution and current status of bacterial blight and fungal diseases of cassava in Nigeria. International institute of tropical Agriculture, 1-5.

Otim-Nape, G. W. (1980). Cassava Bacterial Blight in Uganda. Tropical Pest Management, 26(3), 274-277.

Simon, B., Willy, T. H., Obiero, H., Gashaka, G., Mkamilo, G., Ndyetabula, I., Jeremiah, S., \& Titus, A. (2010). Cassava Disease Surveillance Surveys 2009. International institute of Tropical Agriculture.

Terry, E. R. (1974). Factors Affecting the Incidence of Cassava Bacterial Blight in Africa. In Trujillo, C. A., Ochoa, J. C., Mideros, M. F., \& Restrepo, S. (2014), A Complex Population Structure of the Cassava Pathogen Xanthomonas axonopodis pv . manihotis in Recent Years in the Caribbean Region of Colombia (pp. 155- 
167). https://doi.org/10.1007/s00248-014-0411-8

Verdier, V., Boher, B., Maraite, H., \& Geiger, J. P. (1994). Pathological and molecular characterization of Xanthomonas campestris strains causing diseases of cassava (Manihot esculenta). Applied and Environmental Microbiology, 60(12), 4478-4486. https://doi.org/10.1128/aem.60.12.4478-4486.1994

\section{Copyrights}

Copyright for this article is retained by the author(s), with first publication rights granted to the journal.

This is an open-access article distributed under the terms and conditions of the Creative Commons Attribution license (http://creativecommons.org/licenses/by/4.0/). 